\title{
Anthraquinone Siloxanes as Thickening Agents for Supercritical $\mathrm{CO}_{2}$ Synthetic Details and NMR Data
}

\section{Synthesis of Simple Linear PDMS-Bisamides}

The aminopropyl functional polysiloxanes (1.0 equivalent) were combined with excess triethylamine (1.05 equivalents) in hexane or hexane/chloroform blends. More hexane was used with GAP-10 as the siloxane input. More chloroform was used as the siloxane chain length decreased. The appropriate acid chloride (1.0 equivalent) in chloroform was then added dropwise under nitrogen. After stirring at least 3 hours, the reaction mixture was filtered into a separatory funnel. This was then washed twice with water and once with saturated sodium chloride. After drying over anhydrous potassium carbonate, the solvents were removed on a rotary evaporator, yielding the final product.

Compound 3a (bisbenzamide terminated PDMS, $x=10)$. The yield was $28.4 \mathrm{~g}(95 \%)$ as a viscous yellow oil. ${ }^{1} \mathrm{H}$ NMR $\left(\mathrm{CDCl}_{3}\right) \delta$ : $7.79(\mathrm{~m}, 4 \mathrm{H}) ; 7.46(\mathrm{~m}, 6 \mathrm{H}) ; 6.2-7.0$ (series of br m, 2H); $3.45(\mathrm{~m}, 4 \mathrm{H}) ; 1.66(\mathrm{~m}, 4 \mathrm{H})$; $0.62(\mathrm{~m}, 4 \mathrm{H}) ; 0.05-0.12$ (series of $\mathrm{s}, 78 \mathrm{H}) .{ }^{13} \mathrm{C}\left\{{ }^{1} \mathrm{H}\right\} \mathrm{NMR}\left(\mathrm{CDCl}_{3}\right): 167.63,134.81,131.13,128.34,127.01$, $42.99,23.53,15.47,1.16,1.01,0.09 \mathrm{ppm}$.

Compound 3b (bisbenzamide terminated PDMS, $\mathrm{x}=5)$. The yield was $30.5 \mathrm{~g}(92 \%)$ as a viscous yellow oil. ${ }^{1} \mathrm{H}$ NMR $\left(\mathrm{CDCl}_{3}\right) 7.79(\mathrm{~m}, 4 \mathrm{H}) ; 7.42(\mathrm{~m}, 6 \mathrm{H}) ; 6.3-7.1$ (series of br $\left.\mathrm{m}, 2 \mathrm{H}\right) ; 3.43(\mathrm{~m}, 4 \mathrm{H}) ; 1.65(\mathrm{~m}, 4 \mathrm{H})$; $0.60(\mathrm{~m}, 4 \mathrm{H}) ; 0.03-0.12$ (series of $\mathrm{s}, 42 \mathrm{H}) .{ }^{13} \mathrm{C}\left\{{ }^{1} \mathrm{H}\right\} N M R\left(\mathrm{CDCl}_{3}\right): 167.48,134.88,131.26,128.49,126.88$, $42.92,23.60,15.47,1.20,1.07,0.15 \mathrm{ppm}$.

Compound 3c (bisbenzamide terminated PDMS, $\mathrm{x}=1$ ). The yield was $31.2 \mathrm{~g}(76 \%)$ as a viscous yellow oil. ${ }^{1} \mathrm{H} \mathrm{NMR}\left(\mathrm{CDCl}_{3}\right) 7.81(\mathrm{~m}, 4 \mathrm{H}) ; 7.41(\mathrm{~m}, 6 \mathrm{H}) ; 6.4-7.1$ (series of br $\left.\mathrm{m}, 2 \mathrm{H}\right) ; 3.42(\mathrm{~m}, 4 \mathrm{H}) ; 1.65(\mathrm{~m}, 4 \mathrm{H}) ; 0.59$ $(\mathrm{m}, 4 \mathrm{H}) ; 0.02-0.11$ (series of $\mathrm{s}, 18 \mathrm{H}) .{ }^{13} \mathrm{C}\left\{{ }^{1} \mathrm{H}\right\} N M R\left(\mathrm{CDCl}_{3}\right): 167.64,134.85,131.18,128.42,127.02,43.07$, $23.69,15.62,1.34,1.23,0.37,0.17 \mathrm{ppm}$.

Compound 4a (bis(4-methoxybenzamide) terminated PDMS, $\mathrm{x}=10$ ). The yield was $17.6 \mathrm{~g}(92 \%)$ as a viscous yellow oil. ${ }^{1} \mathrm{H}$ NMR $\left(\mathrm{CDCl}_{3}\right) 7.76(\mathrm{~m}, 4 \mathrm{H}) ; 6.89(\mathrm{~m}, 4 \mathrm{H}) ; 6.3-6.7$ (series of br m, 2H); $3.83(\mathrm{~s}, 6 \mathrm{H})$, $3.41(\mathrm{~m}, 4 \mathrm{H}) ; 1.64(\mathrm{~m}, 4 \mathrm{H}) ; 0.60(\mathrm{~m}, 4 \mathrm{H}) ; 0.02-0.11$ (series of $\mathrm{s}, 74 \mathrm{H}) .{ }^{13} \mathrm{C}\left\{{ }^{1} \mathrm{H}\right\} \mathrm{NMR}\left(\mathrm{CDCl}_{3}\right): 168.96,161.98$, $128.65,127.16,113.63,55.32,42.86,23.66,15.48,1.19,1.04,0.13$ ppm.

Compound 4b (bis(4-methoxybenzamide) terminated PDMS, $\mathrm{x}=5$ ). The yield was $18.7 \mathrm{~g}(87 \%)$ as a viscous yellow oil. ${ }^{1} \mathrm{H}$ NMR $\left(\mathrm{CDCl}_{3}\right) 7.76(\mathrm{~m}, 4 \mathrm{H}) ; 6.85(\mathrm{~m}, 4 \mathrm{H}) ; 6.5-7.2$ (series of br $\mathrm{t}, \mathrm{J}=5.6 \mathrm{~Hz}, 2 \mathrm{H}$ ); 3.783.81 (series of $\mathrm{s}, 6 \mathrm{H}), 3.38(\mathrm{~m}, 4 \mathrm{H}) ; 1.62(\mathrm{~m}, 4 \mathrm{H}) ; 0.57(\mathrm{~m}, 4 \mathrm{H}) ; 0.00-0.09$ (series of $\mathrm{s}, 42 \mathrm{H}) .{ }^{13} \mathrm{C}\left\{{ }^{1} \mathrm{H}\right\} \mathrm{NMR}$ $\left(\mathrm{CDCl}_{3}\right): 167.01,161.94,128.69,127.15,113.59,55.29,42.89,23.64,15.48,1.31,1.21,1.04,0.34,0.12$ ppm.

Compound 4c (bis(4-methoxybenzamide) terminated PDMS, $\mathrm{x}=1$ ). The yield was $23.6 \mathrm{~g}(86 \%)$ as a viscous yellow oil. ${ }^{1} \mathrm{H}$ NMR $\left(\mathrm{CDCl}_{3}\right) 7.78(\mathrm{~m}, 4 \mathrm{H}) ; 6.84(\mathrm{~m}, 4 \mathrm{H})$; $6.65-7.15$ (series of br t, J = 6.0 Hz, $2 \mathrm{H}$ ); 3.78-3.81 (series of $\mathrm{s}, 6 \mathrm{H}), 3.37(\mathrm{~m}, 4 \mathrm{H}) ; 1.63(\mathrm{~m}, 4 \mathrm{H}) ; 0.55(\mathrm{~m}, 4 \mathrm{H}) ; 0.00-0.09$ (series of $\mathrm{s}, 18 \mathrm{H})$. 
${ }^{13} \mathrm{C}\left\{{ }^{1} \mathrm{H}\right\} N M R\left(\mathrm{CDCl}_{3}\right): 167.21,161.88,128.86,127.15,113.53,55.29,43.04,23.72,15.62,1.33,1.22,0.34$, $0.16 \mathrm{ppm}$.

Compound 5a (bis(naphthylcarboxamide) terminated PDMS, $\mathrm{x}=10$ ). The yield was $17.2 \mathrm{~g}(87 \%)$ as a viscous yellow oil. ${ }^{1} \mathrm{H} \mathrm{NMR}\left(\mathrm{CDCl}_{3}\right) 8.32(\mathrm{~m}, 2 \mathrm{H}), 7.84(\mathrm{~m}, 8 \mathrm{H}) ; 7.51(\mathrm{~m}, 4 \mathrm{H})$ 6.74-7.36 (series of br $\mathrm{t}, \mathrm{J}=$ $6.0 \mathrm{~Hz}, 2 \mathrm{H}) ; 3.50(\mathrm{~m}, 4 \mathrm{H}) ; 1.71(\mathrm{~m}, 4 \mathrm{H}) ; 0.64(\mathrm{~m}, 4 \mathrm{H}), 0.05-0.15$ (series of $\mathrm{s}, 70 \mathrm{H}) .{ }^{13} \mathrm{C}\left\{{ }^{1} \mathrm{H}\right\} \mathrm{NMR}\left(\mathrm{CDCl}_{3}\right)$ : $167.60,134.64,132.64,132.12,128.88,128.31,127.70,127.47,127.32,126.62,123.72$, 43.12, 23.67, $15.55,1.24,1.08,0.16 \mathrm{ppm}$.

Compound 5b (bis(naphthylcarboxamide) terminated PDMS, $\mathrm{x}=5$ ). The yield was $19.7 \mathrm{~g}(88 \%)$ as a viscous yellow oil. ${ }_{1} \mathrm{H}$ NMR $\left(\mathrm{CDCl}_{3}\right) 8.33(\mathrm{~m}, 2 \mathrm{H}) ; 7.89(\mathrm{~m}, 2 \mathrm{H}) ; 7.6-7.8(\mathrm{~m}, 6 \mathrm{H}) ; 7.43(\mathrm{~m}, 4 \mathrm{H})$ 7.2-7.6 (series of br m, 2H); $3.49(\mathrm{~m}, 4 \mathrm{H}) ; 1.71(\mathrm{~m}, 4 \mathrm{H}) ; 0.61(\mathrm{~m}, 4 \mathrm{H}), 0.04-0.18$ (series of s, $42 \mathrm{H}) .{ }^{13} \mathrm{C}\left\{{ }^{1} \mathrm{H}\right\} \mathrm{NMR}\left(\mathrm{CDCl}_{3}\right)$ : $167.80,134.60,132.61,132.12,128.88,128.21,127.65,127.44,126.54,123.99,123.84,43.12$, 23.66, $15.58,1.28,1.17,1.14,0.39,0.18 \mathrm{ppm}$.

Compound 6a (bis(4-nitrobenzamide) terminated PDMS, $\mathrm{x}=10)$. The yield was $17.8 \mathrm{~g}(91 \%)$ as a yellow wax. ${ }^{1} \mathrm{H}$ NMR $\left(\mathrm{CDCl}_{3}\right) 8.25(\mathrm{~m}, 4 \mathrm{H}) ; 7.95(\mathrm{~m}, 4 \mathrm{H}) ; 6.45-7.25$ (series of br $\left.\mathrm{m}, 2 \mathrm{H}\right) ; 3.46(\mathrm{~m}, 4 \mathrm{H}) ; 1.69(\mathrm{~m}$, $4 \mathrm{H}) ; 0.62(\mathrm{~m}, 4 \mathrm{H}) ; 0.03-0.13$ (series of $\mathrm{s}, 71 \mathrm{H}) .{ }^{13} \mathrm{C}\left\{{ }^{1} \mathrm{H}\right\} \mathrm{NMR}\left(\mathrm{CDCl}_{3}\right): 165.41,149.44,140.46,128.11$, $123.74,43.21,23.48,15.47,1.19,1.03,0.13 \mathrm{ppm}$.

Compound $6 \mathbf{b}$ (bis(4-nitrobenzamide) terminated PDMS, $x=5)$. The yield was $19.9 \mathrm{~g}(90 \%)$ as a yellow wax. ${ }^{1} \mathrm{H} \mathrm{NMR}\left(\mathrm{CDCl}_{3}\right) 8.18(\mathrm{~m}, 4 \mathrm{H}) ; 7.94(\mathrm{~m}, 4 \mathrm{H}) ; 6.82-7.62$ (series of br $\left.\mathrm{t}, \mathrm{J}=6.0 \mathrm{~Hz}, 2 \mathrm{H}\right) ; 3.42(\mathrm{~m}, 4 \mathrm{H})$; $1.65(\mathrm{~m}, 4 \mathrm{H}) ; 0.58(\mathrm{~m}, 4 \mathrm{H}),-0.01-0.09$ (series of $\mathrm{s}, 41 \mathrm{H}) .{ }^{13} \mathrm{C}\left\{{ }^{1} \mathrm{H}\right\} N M R\left(\mathrm{CDCl}_{3}\right): 165.52,149.33,140.47$, $140.43,128.27,128.18,123.62,43.26,23.42,15.47,1.28,1.16,1.02,0.29,0.13$ ppm.

Compound 7a (bis(4-nitrobenzamide) terminated PDMS, $x=25)$. Aminopropyl terminated PDMS GAP25 (10.0 g, $\sim 9.5 \mathrm{mmol} \mathrm{NH}_{2}$ ) was dissolved in chloroform $(20 \mathrm{~mL})$ under nitrogen. Next, triethylamine (1.8 $\mathrm{mL}, 12.9 \mathrm{mmol}$ ) was added followed by solid biphenylcarbonyl chloride ( $2.27 \mathrm{~g}, 10.5 \mathrm{mmol})$. After stirring over a weekend, hexanes $(40 \mathrm{~mL})$ were added to precipitate $\mathrm{Et}_{3} \mathrm{NHCl}$. A large amount of solid formed so I added a little more chloroform. At this point the ratio of the two solvents was about 1:1. After filtering out the solids, the resulting solution was washed twice with DI water and once with saturated $\mathrm{NaCl}$, and then dried over potassium carbonate. The solvents were then removed on a rotary evaporator yielding $10.08 \mathrm{~g}$ of product as a waxy solid. The melting behavior of this material was evaluated using differential scanning calorimetry (DSC, Perkin-Elmer DSC7, heating rate of $10^{\circ} \mathrm{C} / \mathrm{min}$ ). The melting endotherm exhibited an Onset Temperature of $92.38^{\circ} \mathrm{C}$, a Peak Temperature of $102.07^{\circ} \mathrm{C}$ and a Delta $\mathrm{H}$ of $2.494 \mathrm{~J} / \mathrm{g}$. ${ }^{1} \mathrm{H} \mathrm{NMR}\left(\mathrm{CDCl}_{3}\right) \delta: 7.88(\mathrm{~d}, \mathrm{~J}=8.4 \mathrm{~Hz}, 4 \mathrm{H}) ; 7.66(\mathrm{~d}, \mathrm{~J}=8.0 \mathrm{~Hz}, 4 \mathrm{H}) ; 7.62(\mathrm{~d}, \mathrm{~J}=$ $7.6 \mathrm{~Hz}, 4 \mathrm{H}) ; 7.48(\mathrm{t}, \mathrm{J}=7.6 \mathrm{~Hz}, 4 \mathrm{H}) ; 7.40(\mathrm{t}, \mathrm{J}=7.6 \mathrm{~Hz}, 2 \mathrm{H}) ; 6.40-7.15(\mathrm{~m}, 2 \mathrm{H}) ; 3.50(\mathrm{br} \mathrm{q}, \mathrm{J}=6.8 \mathrm{~Hz}, 4 \mathrm{H})$; $1.71(\mathrm{~m}, 4 \mathrm{H}) ; 0.66(\mathrm{~m}, 4 \mathrm{H}) ; 0.12$ (br s, $158 \mathrm{H}) .{ }^{13} \mathrm{C}\left\{{ }^{1} \mathrm{H}\right\} \mathrm{NMR}\left(\mathrm{CDCl}_{3}\right): 167.14,144.09,140.09,133.57$, $128.91,127.94,127.43,127.18,42.96,23.67,15.52,1.21,1.10,1.04,0.16$ ppm.

Compound 7b (bis(4-nitrobenzamide) terminated PDMS, $x=40)$. Gelest DMS-A15 (10.0 g, 6.2 mmol $\mathrm{NH}_{2}$ ) was dissolved in chloroform $(20 \mathrm{~mL})$ under nitrogen. Next, triethylamine $(1.5 \mathrm{~mL}, 10.8 \mathrm{mmol})$ was 
added followed by 4-biphenylcarbonyl chloride (1.34 g, $6.2 \mathrm{mmol})$. After stirring overnight at room temperature, hexanes $(50 \mathrm{~mL})$ were added to precipitate $\mathrm{Et}_{3} \mathrm{NHCl}$ which was then filtered out. The resulting solution was washed three times with $\mathrm{DI}$ water and once with saturated $\mathrm{NaCl}$, and dried over potassium carbonate. The solvents were then removed on a rotary evaporator yielding $9.75 \mathrm{~g}$ of product as a waxy solid. The melting behavior of this material was evaluated using differential scanning calorimetry (DSC, Perkin-Elmer DSC7, heating rate of $10^{\circ} \mathrm{C} / \mathrm{min}$ ). The melting endotherm exhibited an Onset Temperature of $68.81^{\circ} \mathrm{C}$, a Peak Temperature of $90.07^{\circ} \mathrm{C}$ and a Delta $\mathrm{H}$ of $4.419 \mathrm{~J} / \mathrm{g}$. ${ }^{1} \mathrm{H} \mathrm{NMR}$ $\left(\mathrm{CDCl}_{3}\right) \delta: 7.89(\mathrm{~d}, \mathrm{~J}=8.4 \mathrm{~Hz}, 4 \mathrm{H}) ; 7.65(\mathrm{~d}, \mathrm{~J}=8.0 \mathrm{~Hz}, 4 \mathrm{H}) ; 7.61(\mathrm{~d}, \mathrm{~J}=8.0 \mathrm{~Hz}, 4 \mathrm{H}) ; 7.47(\mathrm{t}, \mathrm{J}=8.0 \mathrm{~Hz}, 4 \mathrm{H})$; $7.39(\mathrm{t}, \mathrm{J}=7.6 \mathrm{~Hz}, 2 \mathrm{H}) ; 6.55-7.05(\mathrm{~m}, 2 \mathrm{H}) ; 3.51(\mathrm{br} \mathrm{q}, \mathrm{J}=6.4 \mathrm{~Hz}, 4 \mathrm{H}) ; 1.72(\mathrm{~m}, 4 \mathrm{H}) ; 0.66(\mathrm{~m}, 4 \mathrm{H}) ; 0.13(\mathrm{br} \mathrm{s}$, 267H). ${ }^{13} \mathrm{C}\left\{{ }^{1} \mathrm{H}\right\}$ NMR $\left(\mathrm{CDCl}_{3}\right): 167.18,144.06,140.09,133.56,128.88,127.91,127.48,127.16,127.13$, $42.99,23.67,15.53,1.40,1.20,1.03,0.66,0.14 \mathrm{ppm}$.

Compound 8 (bis(anthraquinone-2-carboxamide) terminated PDMS, $x=50$ ). Aminopropyl terminated PDMS GAP-50 $\left(10.0 \mathrm{~g}, 5.05 \mathrm{mmol} \mathrm{NH}_{2}\right.$ ) was dissolved in a blend of chloroform ( $\left.30 \mathrm{~mL}\right)$ and hexanes (20 $\mathrm{mL}$ ) under nitrogen and then triethylamine $(1.0 \mathrm{~mL}, 7.2 \mathrm{mmol})$ was added followed by anthraquinone-2carbonyl chloride $(1.42 \mathrm{~g}, 5.25 \mathrm{mmol})$. After stirring overnight at room temperature, the reaction mixture was filtered to remove $\mathrm{Et}_{3} \mathrm{NHCl}$. The resulting solution was washed three times with DI water and once with saturated $\mathrm{NaCl}$, and then dried over potassium carbonate. The solvents were then removed on a rotary evaporator yielding $10.42 \mathrm{~g}$ of product as a yellow oil that solidified on cooling to a clear yellow material. The melting behavior of this material was evaluated using differential scanning calorimetry (DSC, Perkin-Elmer DSC7, heating rate of $10^{\circ} \mathrm{C} / \mathrm{min}$ ). The melting endotherm was multimodal with an overall Delta $\mathrm{H}$ of $2.748 \mathrm{~J} / \mathrm{g}$. The main peak had an Onset Temperature of $46.75^{\circ} \mathrm{C}$ and a Peak Temperature of $48.00^{\circ} \mathrm{C}$. ${ }^{1} \mathrm{H} \mathrm{NMR}\left(\mathrm{CDCl}_{3}\right) \delta: 8.55(\mathrm{~s}, 2 \mathrm{H}) ; 8.25-8.38(\mathrm{~m}, 8 \mathrm{H}) ; 7.82(\mathrm{~m}, 4 \mathrm{H}) ; 6.6-7.5$ $(\mathrm{m}, 2 \mathrm{H}) ; 3.53$ (br q, J = 7.0 Hz, 4H); $1.74(\mathrm{~m}, 4 \mathrm{H}) ; 0.67(\mathrm{~m}, 4 \mathrm{H}) ; 0.08-0.15(\mathrm{~m}, 318 \mathrm{H}) .{ }^{13} \mathrm{C}\left\{{ }^{1} \mathrm{H}\right\} \mathrm{NMR}\left(\mathrm{CDCl}_{3}\right)$ : $182.45,182.36,165.51,139.81,134.99,134.41,134.33,133.38,133.34,133.14,127.84,127.35,124.78$, $43.31,23.59,15.54,1.39,1.19,1.07,1.01,0.93,0.84,0.72,0.64,0.13$ ppm.

Compound 9 (branched aminosilicone). The following inputs were combined and heated to $80^{\circ} \mathrm{C}$ under nitrogen: GAP-0 (8.62 g, 34.7 mmol, 69.4 mmol M'), methyltriethoxysilane (3.63 g, 20.4 mmol), Gelest DMS-S12 (21.0 g, 76 mmol OH, $266 \mathrm{mmol} \mathrm{D})$, D4 (71.0 g, $958 \mathrm{mmol}$ D), and tetramethyammonium hydroxide pentahydrate $(0.8 \mathrm{~g}, 4.4 \mathrm{mmol} \mathrm{OH})$. After an hour and a half the hazy blend was placed under a light house vacuum to remove volatiles (ethanol, water, etc.). This caused the mixture to clarify. After a couple of hours under vacuum, the blend was returned to atmospheric pressure, $20 \mathrm{~mL}$ toluene was added and then about half was stripped off under vacuum. A nitrogen atmosphere was then reestablished and the reaction was allowed to equilibrate overnight. At this point the rest of the toluene was stripped off under vacuum. Proton NMR showed there was still a small amount of ethoxy groups present. Thus I added water $(0.5 \mathrm{~mL})$ and more toluene $(5 \mathrm{~mL})$. The mixture was then heated up to $90^{\circ} \mathrm{C}$ for a while. Next the reaction mixture was placed under vacuum and the temperature was increased until it eventually reached $\sim 175^{\circ} \mathrm{C}$. During this time volatiles were being stripped off and the catalyst thermally decomposed. Once the strip was complete, the crude product was cooled to room temperature, Celite $(2 \mathrm{~g})$ was added and the material was filtered. The result was $87.2 \mathrm{~g}$ of product as a 
clear, colorless oil. ${ }^{1} \mathrm{H}$ NMR $\left(\mathrm{CDCl}_{3}\right) \delta: 2.69(\mathrm{t}, \mathrm{J}=7.2 \mathrm{~Hz}, 6 \mathrm{H}) ; 1.48(\mathrm{~m}, 6 \mathrm{H}) ; 1.13(\mathrm{br} \mathrm{s}, 6 \mathrm{H}) ; 0.55(\mathrm{~m}, 6 \mathrm{H})$; 0.09 (br s, 377H). $\left.{ }^{29} \mathrm{Si} \mathrm{NMR} \mathrm{(} \mathrm{CDCl}_{3} / \mathrm{Cr}(\mathrm{acac})_{3}\right)$ : 5.05 (M'); -21.68, -21.86, -24.05, -24.52, -24.67 (D groups); $-67.76,-68.92,-69.60 .-69.89$ (T groups); M:D:T ratio = 3:57:1.1.

Compound 10 (branched aminosilicone). The following inputs were combined and heated to $90^{\circ} \mathrm{C}$ under nitrogen: GAP-0 (7.46 g, $\left.30.0 \mathrm{mmol}, 60.0 \mathrm{mmol} \mathrm{M}^{\prime}\right)$, methyltriethoxysilane ( $\left.9.38 \mathrm{~g}, 52.6 \mathrm{mmol}\right)$, Gelest DMS-S12 (43.5 g, $158 \mathrm{mmol} \mathrm{OH}, 550 \mathrm{mmol} \mathrm{D}), \mathrm{D} 4(48.21 \mathrm{~g}, 650 \mathrm{mmol}$ ), and tetramethyammonium hydroxide pentahydrate $(0.8 \mathrm{~g}, 4.4 \mathrm{mmol} \mathrm{OH})$. After 1.5 hours a small amount of water $(0.5 \mathrm{~mL})$ was also added. An hour later the blend was placed under a light house vacuum to remove volatiles (ethanol, water, etc..). After a couple of hours under vacuum, $40 \mathrm{~mL}$ toluene were added and then stripped off under vacuum. Proton NMR showed there was still a small amount ( $5 \%)$ of ethoxy groups present. Thus I added water $(1 \mathrm{~mL})$ and heated the reaction up to $95^{\circ} \mathrm{C}$ where it was kept overnight. Next the reaction mixture was placed under vacuum and the temperature was increased to strip off the volatiles. The mixture seemed to be very prone to excessive foaming especially as the temperature reached about $130-140^{\circ} \mathrm{C}$. Some material was carried over with the volatiles during this time so some yield was lost. Eventually the product was stripped up to $175^{\circ} \mathrm{C}$. Once the strip was complete, the crude product was cooled to room temperature, Celite $(2 \mathrm{~g})$ was added and the material was filtered. The result was 77.4 g of product as a clear, colorless oil. ${ }^{1} \mathrm{H} \mathrm{NMR}\left(\mathrm{CDCl}_{3}\right) \delta: 3.76(\mathrm{q}, \mathrm{J}=7.2 \mathrm{~Hz}, 0.69 \mathrm{H}$, residual ethoxy); $2.68(\mathrm{t}$, $\mathrm{J}=7.2 \mathrm{~Hz}, 8 \mathrm{H}) ; 1.48(\mathrm{~m}, 6 \mathrm{H}) ; 1.22(\mathrm{t}, \mathrm{J}=7.2 \mathrm{~Hz}, 0.91 \mathrm{H}$, residual ethoxy); 1.13 (br s, 6H); 0.55 (m, 6H); 0.09 (br s, 537H). $\left.{ }^{29} \mathrm{Si} \mathrm{NMR} \mathrm{(} \mathrm{CDCl}_{3} / \mathrm{Cr}(\mathrm{acac})_{3}\right): 8.18,7.75,7.67,7.52$ (M' groups); -21.41, -21.48, -21.79, 21.90, -21.96, -22.05 (D groups); -65.14, -66.32, -67.00, -67.22, -67.27, -67.80 (T groups); M:D:T ratio = 4:76:3.6.

Compound 11 (branched aminosilicone). The following inputs were combined and heated to $90^{\circ} \mathrm{C}$ under nitrogen: GAP-0 (7.46 g, $\left.30.0 \mathrm{mmol}, 60.0 \mathrm{mmol} \mathrm{M}^{\prime}\right)$, methyltriethoxysilane ( $\left.9.38 \mathrm{~g}, 52.6 \mathrm{mmol}\right)$, Gelest DMS-S12 (43.5 g, $158 \mathrm{mmol} \mathrm{OH,} 550 \mathrm{mmol}$ ), D4 (67.8 g, $914 \mathrm{mmol}$ ), and tetramethyammonium hydroxide (1.6 $\mathrm{mL} 25 \%$ in water, $4.5 \mathrm{mmol} \mathrm{OH})$. An hour later the blend was placed under a light house vacuum to remove volatiles (ethanol, water, etc..). After a couple of hours under vacuum, $40 \mathrm{~mL}$ toluene were added and then stripped off under vacuum. The reaction was then allowed to proceed overnight under nitrogen. Next the reaction mixture was placed under vacuum and the temperature was increased to strip off the volatiles. The mixture seemed to be very prone to excessive foaming especially as the temperature reached about $130-140^{\circ} \mathrm{C}$. Some material was carried over with the volatiles during this time so some yield was lost. Eventually the product was stripped up to $175^{\circ} \mathrm{C}$. Once the strip was complete, the crude product was cooled to room temperature, Celite $(2 \mathrm{~g})$ was added and the material was filtered. The result was $85 \mathrm{~g}$ of product as a clear, colorless oil. ${ }^{1} \mathrm{H} \mathrm{NMR}\left(\mathrm{CDCl}_{3}\right) \delta: 2.69$ $(\mathrm{t}, \mathrm{J}=7.2 \mathrm{~Hz}, 8 \mathrm{H}) ; 1.48(\mathrm{~m}, 8 \mathrm{H}) ; 1.13(\mathrm{br} \mathrm{s}, 8 \mathrm{H}) ; 0.55(\mathrm{~m}, 8 \mathrm{H}) ; 0.06-0.13(\mathrm{~m}, 608 \mathrm{H}) .{ }^{29} \mathrm{Si} \mathrm{NMR}$ $\left(\mathrm{CDCl}_{3} / \mathrm{Cr}\left(\mathrm{acac}_{3}\right): 7.64\right.$ (M' group); -21.43, -21.50, -21.66, -21.92, -22.09, -22.16 (D groups); -65.16, $65.67,-66.35,-67.02,-67.29,-67.82$ (T groups); M:D:T ratio = 4:88:3.5.

Compound 12 (anthraquinone-2-carboxamide terminated branched polymer). Branched aminosilicone 9 $\left(10.0 \mathrm{~g}, 6.37 \mathrm{mmol} \mathrm{NH}_{2}\right)$ was dissolved in chloroform $(30 \mathrm{~mL})$ under nitrogen. Next, triethylamine (1.0 
$\mathrm{mL}, 7.2 \mathrm{mmol}$ ) was added followed by anthraquinone-2-carbonyl chloride $(1.72 \mathrm{~g}, 6.36 \mathrm{mmol})$. After stirring 4 hours, hexanes $\left(50 \mathrm{~mL}\right.$ ) were added to precipitate $\mathrm{Et}_{3} \mathrm{NHCl}$ which was then filtered out. The resulting solution was washed twice with $\mathrm{DI}$ water and once with saturated $\mathrm{NaCl}$, and then dried over potassium carbonate. The solvents were then removed on a rotary evaporator yielding $9.98 \mathrm{~g}$ of product as a yellow oil that solidified on cooling to a clear yellow material. ${ }^{1} \mathrm{H} N M R\left(\mathrm{CDCl}_{3}\right) \delta: 8.49(\mathrm{~s}$, $3 \mathrm{H}) ; 8.22(\mathrm{~m}, 12 \mathrm{H}) ; 7.76(\mathrm{~m}, 6 \mathrm{H}) ; 6.8-7.4(\mathrm{~m}, 3 \mathrm{H}) ; 3.53 \mathrm{q}, \mathrm{J}=6.8 \mathrm{~Hz}, 6 \mathrm{H}) ; 1.74(\mathrm{~m}, 6 \mathrm{H}) ; 0.67(\mathrm{~m}, 6 \mathrm{H}) ; 0.03-$ $0.15(\mathrm{~m}, 388 \mathrm{H}) .{ }^{13} \mathrm{C}\left\{{ }^{1} \mathrm{H}\right\}$ NMR $\left(\mathrm{CDCl}_{3}\right): 182.28,182.23,165.61,139.85,134.86,134.30,134.24,133.26$, $133.06,127.70,127.25,124.85,43.33,23.57,15.55,1.36,1.17,0.99,0.91,0.81,0.70,0.62,0.13$ ppm.

Compound 13 (anthraquinone-2-carboxamide terminated branched polymer). Branched aminosilicone 10 (23.0 g, $13.8 \mathrm{mmol} \mathrm{NH2}$ ) was dissolved in chloroform $(65 \mathrm{~mL})$ under nitrogen. Next, triethylamine $(2.5$ $\mathrm{mL}, 17.9 \mathrm{mmol}$ ) was added followed by anthraquinone-2-carbonyl chloride (3.73 g, $13.8 \mathrm{mmol})$. After stirring overnight, hexanes $(90 \mathrm{~mL})$ and Celite $(3 \mathrm{~g})$ were added and the mixture was filtered. There appeared to be a little bit of gel on the walls of the filter flask, so a little more Celite ( $2 \mathrm{~g})$ was added and the mix was refiltered. The resulting solution was then stripped on a rotary evaporator. The result was $27.9 \mathrm{~g}$ of a slightly hazy material. Therefore it was dissolved in chloroform and washed twice with DI water. The phase separations took some time to finish (there was a stubbornly persistent rag layer in the top water phase). After drying over potassium carbonate, the solvent was then removed on a

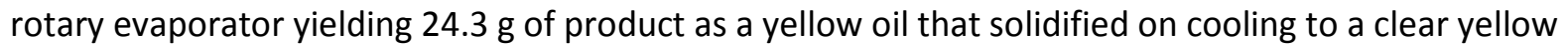
material. The melting behavior of this material was evaluated using differential scanning calorimetry (DSC, Perkin-Elmer DSC7, heating rate of $10^{\circ} \mathrm{C} / \mathrm{min}$ ). The melting endotherm exhibited an Onset Temperature of $47.65^{\circ} \mathrm{C}$, a Peak Temperature of $49.80^{\circ} \mathrm{C}$ and a Delta $\mathrm{H}$ of $5.459 \mathrm{~J} / \mathrm{g} .{ }^{1} \mathrm{H} \mathrm{NMR}\left(\mathrm{CDCl}_{3}\right) \delta$ : $8.57(\mathrm{~s}, 4 \mathrm{H}) ; 8.25-8.40(\mathrm{~m}, 16 \mathrm{H}) ; 7.83(\mathrm{~m}, 8 \mathrm{H}) ; 6.5-7.2(\mathrm{~m}, 4 \mathrm{H}) ; 3.76(\mathrm{q}, \mathrm{J}=6.8 \mathrm{~Hz}, 0.78 \mathrm{H}$ residual ethoxy); $3.53 \mathrm{q}, \mathrm{J}=6.4 \mathrm{~Hz}, 8 \mathrm{H}) ; 1.73(\mathrm{~m}, 8 \mathrm{H}) ; 1.22(\mathrm{t}, \mathrm{J}=6.8 \mathrm{~Hz}, 1.29 \mathrm{H}$, residual ethoxy); $0.66(\mathrm{~m}, 8 \mathrm{H}) ; 0.07-0.15$ (m, 569H). ${ }^{13} \mathrm{C}\left\{{ }^{1} \mathrm{H}\right\}$ NMR $\left(\mathrm{CDCl}_{3}\right): 182.51,182.41,165.49,139.80,135.03,134.43,134.36,133.40,133.36$, 133.16, 127.89, 127.39, 124.76, 43.30, 23.59, 15.54, 1.39, 1.20, 1.02, 0.93, 0.85, 0.83, 0.79, 0.69, 0.65, $0.56,0.14 \mathrm{ppm}$.

Compound 14 (anthraquinone-2-carboxamide terminated branched polymer). Branched aminosilicone 11 (10.0 g, $5.5 \mathrm{mmol} \mathrm{NH}$ ) was dissolved in chloroform $(30 \mathrm{~mL})$ under nitrogen. Next, triethylamine (1.0 $\mathrm{mL}, 7.2 \mathrm{mmol}$ ) was added followed by anthraquinone-2-carbonyl chloride (1.50 g, $5.5 \mathrm{mmol})$. After stirring overnight, the reaction mixture was diluted with hexanes $(45 \mathrm{~mL})$ and filtered into a separatory funnel. The resulting solution was washed twice with DI water and once with saturated sodium chloride. After drying over anhydrous potassium carbonate, the solvents were removed on a rotary evaporator to yield $10.48 \mathrm{~g}$ (93\%) of a yellow oil that solidified to a rubbery solid on cooling to room temperature. The melting behavior of this material was evaluated using differential scanning calorimetry (DSC, Perkin-Elmer DSC7, heating rate of $10^{\circ} \mathrm{C} / \mathrm{min}$ ). The melting endotherm exhibited an Onset Temperature of $34.14^{\circ} \mathrm{C}$, a Peak Temperature of $46.53^{\circ} \mathrm{C}$ and a Delta $\mathrm{H}$ of $3.2400 \mathrm{~J} / \mathrm{g} .{ }^{1} \mathrm{H} \mathrm{NMR}\left(\mathrm{CDCl}_{3}\right) \delta$ : $8.57(\mathrm{~s}, 4 \mathrm{H}) ; 8.25-8.40(\mathrm{~m}, 16 \mathrm{H}) ; 7.83(\mathrm{~m}, 8 \mathrm{H}) ; 6.6(\mathrm{br} \mathrm{s}) ; 3.53(\mathrm{q}, \mathrm{J}=6.4 \mathrm{~Hz}, 8 \mathrm{H}) ; 1.74(\mathrm{~m}, 8 \mathrm{H}) ; 0.66(\mathrm{~m}$, $8 \mathrm{H}) ; 0.05-0.16(\mathrm{~m}, 636 \mathrm{H}) .{ }^{13} \mathrm{C}\left\{{ }^{1} \mathrm{H}\right\} \mathrm{NMR}\left(\mathrm{CDCl}_{3}\right): 182.49,182.40,165.49,139.80,135.02,134.43,134.35$, 
$133.39,133.36,133.16,127.89,127.38,124.77,43.30,23.59,15.54,1.39,1.20,1.02,0.93,0.85,0.74$, $0.14,-2.30 \mathrm{ppm}$.

Compound 21 (anthraquinone-2-carboxamide terminated branched polymer). Methyltris(dimethylsiloxy)silane $\left(\mathrm{M}_{3}^{\mathrm{H}} \mathrm{T}, 1.23 \mathrm{~g}, 4.58 \mathrm{mmol}\right.$ ) was dissolved in toluene $(3 \mathrm{~mL})$ under nitrogen. A small drop of Karstedt's catalyst was added and the result was heated to $70^{\circ} \mathrm{C}$. A solution of SL6100 (Momentive Performance Materials, $2.00 \mathrm{~g}, 0.46 \mathrm{mmol}$ ) in toluene $(5 \mathrm{~mL}$ ) was added dropwise over 20 minutes. Fifteen minutes after the addition was complete the reaction was checked by proton NMR. This showed that the vinyls were completely consumed. Therefore the toluene and excess $\mathrm{M}_{3}^{\mathrm{H}} \mathrm{T}$ were removed under vacuum. $1.65 \mathrm{~g}$ of the stripped material (theoretical was $2.12 \mathrm{~g}$ ) was then placed in a clean flask and dissolved in toluene $(5 \mathrm{~mL})$ and heated to $80^{\circ} \mathrm{C}$. Allyl anthraquinone-2-carboxamide $15(0.20 \mathrm{~g}, 0.69 \mathrm{mmol})$ was added followed by another drop of catalyst. The temperature was increased to $95^{\circ} \mathrm{C}$. After a short period of time the solid allyl anthraquinone-2-carboxamide completely dissolved and the reaction color changed from yellow to brown. Proton NMR at this point showed the reaction to be complete. Thus the solvent was removed on a rotary evaporator. The yield was $1.81 \mathrm{~g}$ of product as a rubbery brown solid. The melting behavior of this material was evaluated using differential scanning calorimetry (DSC, Perkin-Elmer DSC7, heating rate of $10^{\circ} \mathrm{C} / \mathrm{min}$ ). The main melting endotherm exhibited an Onset Temperature of $74.7^{\circ} \mathrm{C}$, a Peak Temperature of $80.6^{\circ} \mathrm{C}$ and a Delta $\mathrm{H}$ of $0.97 \mathrm{~J} / \mathrm{g}$. There was also another broad multi-molar endotherm peak with an Onset Temperature of $127.5^{\circ} \mathrm{C}$, a Peak Temperature of $130.5^{\circ} \mathrm{C}$ and a Delta $\mathrm{H}$ of $0.85 \mathrm{~J} / \mathrm{g} .{ }^{1} \mathrm{H} \mathrm{NMR}\left(\mathrm{CDCl}_{3}\right) \delta: 7.6-8.5(\mathrm{~m}, 30 \mathrm{H}), 3.54(\mathrm{~m}, 8 \mathrm{H}), 1.80$ $(\mathrm{m}, 8 \mathrm{H}), 0.70(\mathrm{~m}, 8 \mathrm{H}), 0.47$ (br s, $12 \mathrm{H}), 0.03-0.17(\mathrm{~m}, 955 \mathrm{H}) .{ }^{13} \mathrm{C}\left\{{ }^{1} \mathrm{H}\right\} \mathrm{NMR}(\mathrm{CDCl}): 182.14,166.03,139.95$, $134.41,134.36,134.22,134.19,133.20,133.16,133.13,133.06,127.59,127.39,127.23,127.18,125.09$, $43.50,23.65,15.57,9.46,1.38,1.17,1.01,0.64,0.12,0.03,-0.56$.

Compound 22 (anthraquinone-2-carboxamide terminated branched polymer). Methyltris(dimethylsiloxy)silane $\left(\mathrm{M}_{3}^{\mathrm{H}} \mathrm{T}, 1.00 \mathrm{~g}, 3.72 \mathrm{mmol}\right)$ was dissolved in toluene $(3 \mathrm{~mL})$ under nitrogen. A small drop of Karstedt's catalyst was added and the result was heated to $80-85^{\circ} \mathrm{C}$. A solution of SL6000 (Momentive Performance Materials, $2.00 \mathrm{~g}, 0.36 \mathrm{mmol}$ ) in toluene $(5 \mathrm{~mL}$ ) was added dropwise over 20 minutes. After 30 minutes the toluene and excess $\mathrm{M}_{3}^{\mathrm{H}} \mathrm{T}$ were removed under vacuum. $1.56 \mathrm{~g}$ of the stripped material was then placed in a clean flask and dissolved in toluene $(5 \mathrm{~mL})$ and heated to $80^{\circ} \mathrm{C}$. Allyl anthraquinone-2-carboxamide 15 ( $0.15 \mathrm{~g}, 0.52 \mathrm{mmol}$ ) was added followed by another drop of catalyst. The reaction was then allowed to proceed overnight. The solvent was then removed on a rotary evaporator to yield $1.71 \mathrm{~g}$ of product as a rubbery brown solid. The melting behavior of this material was evaluated using differential scanning calorimetry (DSC, Perkin-Elmer DSC7, heating rate of $10^{\circ} \mathrm{C} / \mathrm{min}$ ). One melting endotherm exhibited an Onset Temperature of $74.15^{\circ} \mathrm{C}$, a Peak Temperature of $80.47^{\circ} \mathrm{C}$ and a Delta $\mathrm{H}$ of $0.76 \mathrm{~J} / \mathrm{g}$. There were also a couple of higher temperature endotherms: one at approximately $128^{\circ} \mathrm{C}$ and the other at $137^{\circ} \mathrm{C} .{ }^{1} \mathrm{H} \mathrm{NMR}\left(\mathrm{CDCl}_{3}\right) \delta$ : 7.6-8.5 $(\mathrm{m}, 31 \mathrm{H})$, $3.55(\mathrm{~m}, 8 \mathrm{H}), 1.80(\mathrm{~m}, 8 \mathrm{H}), 0.70(\mathrm{~m}, 8 \mathrm{H}), 0.47(\mathrm{br} \mathrm{s}, 9 \mathrm{H}), 0.03-0.17(\mathrm{~m}, 1194 \mathrm{H}) .{ }^{13} \mathrm{C}\left\{{ }^{1} \mathrm{H}\right\} \mathrm{NMR}\left(\mathrm{CDCl}_{3}\right)$ : $182.14,166.03,139.96,134.19,133.36,133.16,133.07,127.60,127.40,127.19,127.13,125.09,43.49$, $23.65,15.56,9.45,1.39,1.17,1.01,0.64,0.13,0.03,-0.56$. 
Compound 24 (anthraquinone-2-carboxamide/propyl acetate functional PDMS). Hydride fluid 23 $\left(\mathrm{M}^{\mathrm{H}} \mathrm{D}_{70} \mathrm{D}^{\mathrm{H}}{ }_{7} \mathrm{M}^{\mathrm{H}}\right)(10.0 \mathrm{~g}, 15.7 \mathrm{mmol} \mathrm{SiH})$, solid allyl anthraquinone-2-carboxamide $(2.0 \mathrm{~g}, 6.9 \mathrm{mmol})$ and toluene $(50 \mathrm{~mL})$ were combined and heated to $90-95^{\circ} \mathrm{C}$ under nitrogen. A drop of Karstedt's catalyst in toluene $(1 \mathrm{~mL})$ was then added. The result was stirred for approximately 15-20 minutes during which time all of the allyl anthraquinone-2-carboxamide went into solution. After another 20 minutes, allyl acetate $(1.0 \mathrm{~g}, 10 \mathrm{mmol})$ was added. After another 50 minutes, a small sample was removed, stripped on a rotary evaporator, and analyzed by proton NMR. This showed the reaction to be complete. Therefore, the toluene and excess allyl acetate were removed under vacuum. The result was $11.7 \mathrm{~g}$ of product as a rubbery yellow solid. The melting behavior was evaluated using differential scanning calorimetry (DSC, Perkin-Elmer DSC7, heating rate of $10^{\circ} \mathrm{C} / \mathrm{min}$ ). A tri-modal endotherm was observed. The main melting endotherm exhibited an Onset Temperature of $42.47^{\circ} \mathrm{C}$, a Peak Temperature of $48.93^{\circ} \mathrm{C}$ and a Delta $\mathrm{H}$ of $1.8082 \mathrm{~J} / \mathrm{g}$. The other two endotherms peaked at $\sim 61^{\circ} \mathrm{C}$ and $67^{\circ} \mathrm{C} .{ }^{1} \mathrm{H} \mathrm{NMR}$ $\left(\mathrm{CDCl}_{3}\right)$ 8: 7.6-8.7 (m, 39H), $6.6(\mathrm{br} \mathrm{s}), 4.02(\mathrm{t}, \mathrm{J}=7.0 \mathrm{~Hz}, 7 \mathrm{H}), 3.52(\mathrm{br} \mathrm{q}, \mathrm{J}=6.4 \mathrm{~Hz}, 11 \mathrm{H}), 1.99-2.02(\mathrm{~m}$, $19 \mathrm{H}), 1.6-1.9(\mathrm{~m}, 23 \mathrm{H}), 0.66(\mathrm{~m}, 11 \mathrm{H}), 0.54(\mathrm{~m}, 7 \mathrm{H}), 0.01-0.16(\mathrm{~m}, 715 \mathrm{H}) .{ }^{13} \mathrm{C}\left\{{ }^{1} \mathrm{H}\right\} \mathrm{NMR}\left(\mathrm{CDCl}_{3}\right): 182.48$, $182.39,170.02,165.53,139.80,135.02,134.35,134.14,133.39,133.15,127.87,127.76,124.78,66.82$, $43.30,23.57,23.26,22.69,22.28,20.92,15.53,13.33,1.39,1.18,1.12,1.01,0.84,0.72,0.69,0.64,0.13$, $-0.62,-3.00$.

Compound 27 (fluorenone-2-carboxamide terminated branched polymer). Branched aminosilicone 11 $\left.(10.0 \mathrm{~g}, 5.5 \mathrm{mmol} \mathrm{NH})_{2}\right)$ was dissolved in THF $(30 \mathrm{~mL})$ under nitrogen. Next, triethylamine $(1.0 \mathrm{~mL}, 7.2$ $\mathrm{mmol}$ ) was added followed by fluorenone-2-carbonyl chloride $(1.33 \mathrm{~g}, 5.5 \mathrm{mmol})$. After a couple of hours proton NMR showed the reaction to be complete. Therefore the solids were removed by filtration and then the THF was stripped off on the rotary evaporator. The residue was dissolved in chloroform and washed with water. After drying over anhydrous potassium carbonate, the solvent was removed on a rotary evaporator. The result was $10.02 \mathrm{~g}$ of product as a hazy yellow, rubbery solid. The melting behavior of this material was evaluated using differential scanning calorimetry (DSC, PerkinElmer DSC7, heating rate of $10^{\circ} \mathrm{C} / \mathrm{min}$ ). A multi-modal endotherm in the $40-75^{\circ} \mathrm{C}$ range was observed. The largest peak had an Onset Temperature of $70.80^{\circ} \mathrm{C}$ and a Peak Temperature of $71.60^{\circ} \mathrm{C}$. The delta $\mathrm{H}$ was $4.268 \mathrm{~J} / \mathrm{g} .{ }^{1} \mathrm{H}$ NMR $\left(\mathrm{CDCl}_{3}\right) \delta: 8.08(\mathrm{~d}, \mathrm{~J}=7.6 \mathrm{~Hz}, 4 \mathrm{H}), 7.95(\mathrm{~s}, 4 \mathrm{H}), 7.69(\mathrm{~d}, \mathrm{~J}=7.2 \mathrm{~Hz}, 4 \mathrm{H}), 7.57(\mathrm{~m}$, $12 \mathrm{H}), 7.36(\mathrm{t}, \mathrm{J}=7.4 \mathrm{~Hz}, 4 \mathrm{H}), 6.4(\mathrm{br} \mathrm{s}), 3.49(\mathrm{q}, \mathrm{J}=6.4 \mathrm{~Hz}, 8 \mathrm{H}), 1.70(\mathrm{~m}, 8 \mathrm{H}), 0.65(\mathrm{~m}, 8 \mathrm{H}), 0.02-0.20(\mathrm{~m}$, 581H). ${ }^{13} \mathrm{C}\left\{{ }^{1} \mathrm{H}\right\}$ NMR $\left(\mathrm{CDCl}_{3}\right): 192.89,166.01,146.95,143.53,135.57,134.97,134.60,134.57,134.14$, 129.82 , 124.54, 121.71, 120.96, 120.51, 43.11, 23.59, 15.53, 1.39, 1.18, 1.01, 0.93, 0.84, 0.64, 0.55, 0.13, -2.31 .

Compound 28 (fluorenone-4-carboxamide terminated branched polymer). Branched aminosilicone 11 $(11.2 \mathrm{~g}, 6.2 \mathrm{mmol} \mathrm{NH}$ ) was dissolved in chloroform (30 mL) under nitrogen. Next, triethylamine $(1.0 \mathrm{~mL}$, $7.2 \mathrm{mmol}$ ) was added followed by fluorenone-4-carbonyl chloride $(1.50 \mathrm{~g}, 6.2 \mathrm{mmol})$. The result was allowed to stir under nitrogen overnight at room temperature. At this point the reaction mixture was diluted with $45 \mathrm{~mL}$ of hexanes and filtered into a separatory funnel. The yellow solution was then washed with water- the phase separation was very slow. After drying over anhydrous potassium carbonate, the solvent was removed on a rotary evaporator. A small amount of gel was observed in the crude product, so it was dissolved in chloroform and filtered through Celite. The chloroform was then 
removed to give $9.91 \mathrm{~g}$ of product as a viscous light brown oil. ${ }^{1} \mathrm{H} \mathrm{NMR}\left(\mathrm{CDCl}_{3}\right) \delta: 7.75(\mathrm{br} \mathrm{d}, \mathrm{J}=7.2 \mathrm{~Hz}$, $4 \mathrm{H})$, 7.5-7.6 (m, 8H), $7.42(\mathrm{~m}, 8 \mathrm{H}), 7.28(\mathrm{~m}, 4 \mathrm{H}), 7.19(\mathrm{~m}, 4 \mathrm{H}), 6.4(\mathrm{br} \mathrm{s}), 3.54(\mathrm{~m}, 8 \mathrm{H}), 1.75(\mathrm{~m}, 8 \mathrm{H}), 0.68$ $(\mathrm{m}, 8 \mathrm{H}), 0.05-0.17(\mathrm{~m}, 719 \mathrm{H}) .{ }^{13} \mathrm{C}\left\{{ }^{1} \mathrm{H}\right\}$ NMR $\left(\mathrm{CDCl}_{3}\right): 193.05,168.36,142.96,141.01,135.01,134.83$, $134.03,132.80,132.72,129.38,128.84,125.09,124.14,123.94,43.03,23.51,15.53,1.38,1.17,1.01$, $0.92,0.83,0.72,0.64,0.54,0.14,-2.32$.

Compound 31 (4-(2-carboxyphenylthio) benzoic acid). 4-Bromobenzoic acid (10.0 g, $49.7 \mathrm{mmols})$, thiosalicylic acid $(7.70 \mathrm{~g}, 49.9 \mathrm{mmols})$, copper powder $(0.1 \mathrm{~g})$, and potassium carbonate $(8.0 \mathrm{~g}, 57.9$ mmol) were mixed with DMSO $(100 \mathrm{~mL})$ and heated to $155-160^{\circ} \mathrm{C}$ under nitrogen overnight. The reaction mixture was then allowed to cool some and then it was diluted with several hundred $\mathrm{mLs}$ of deionized water. Activated carbon $(5 \mathrm{~g})$ was added along with a few grams of Celite. After stirring for about 15 minutes the mixture was filtered to remove solids. The filtrate was then acidified using concentrated $\mathrm{HCl}$ causing the product to precipitate. After cooling on ice the solid was collected by vacuum filtration and washed with deionized water. To remove more of the DMSO, the crude product was stirred with another $300 \mathrm{~mL}$ of fresh water and then recollected by vacuum filtration. After drying overnight in the vacuum oven, $10.7 \mathrm{~g}$ (78\% yield) of product were obtained as a white solid. ${ }^{1} \mathrm{H}$ NMR (DMSO- $\mathrm{d}_{6}$ ) $\delta: 13.2(\mathrm{~s}, 2 \mathrm{H}), 7.98(\mathrm{~d}, \mathrm{~J}=8.4 \mathrm{~Hz}, 2 \mathrm{H}), 7.92(\mathrm{dd}, \mathrm{J}=1.6,7.8 \mathrm{~Hz}, 1 \mathrm{H}), 7.56(\mathrm{~d}, \mathrm{~J}=8.4 \mathrm{~Hz}, 2 \mathrm{H}$ ), $7.42(\mathrm{dt}, \mathrm{J}=2.8,7.4 \mathrm{~Hz}, 1 \mathrm{H}), 7.30(\mathrm{dt}, \mathrm{J}=1.0,7.6 \mathrm{~Hz}, 1 \mathrm{H}), 6.95(\mathrm{dd}, \mathrm{J}=1.0,8.0 \mathrm{~Hz}, 1 \mathrm{H}) .{ }^{13} \mathrm{C}\left\{{ }^{1} \mathrm{H}\right\} \mathrm{NMR}$ (DMSO- $d_{6}$ ): $167.89,167.20,139.71,139.05,133.68,132.94,131.20,131.01,129.40,126.40$.

Compound 32 (thioxanthone-2-carboxylic acid). 4-(2-Carboxyphenylthio) benzoic acid $\mathbf{3 1}$ (2.5 g, 9.1 mmol) was combined with Eaton's reagent $(21 \mathrm{~mL})$ and heated under nitrogen to $50^{\circ} \mathrm{C}$ for 3 hours. At this point, the mixture was cooled some and then added with vigorous stirring to deionized water (250 $\mathrm{mL})$. After stirring for 15 minutes, the mix was cooled in an ice bath. The solid product was then collected by vacuum filtration and washed with cold water. After drying in a vacuum oven overnight, 2.3 $\mathrm{g}\left(100 \%\right.$ yield) of product was obtained as an orange solid. ${ }^{1} \mathrm{H}$ NMR (DMSO- $\left.\mathrm{d}_{6}\right) \delta: 11.3(\mathrm{br} \mathrm{s}, 1 \mathrm{H}), 8.92(\mathrm{~d}$, $\mathrm{J}=1.6 \mathrm{~Hz}, 1 \mathrm{H}), 8.41(\mathrm{~d}, \mathrm{~J}=8.0 \mathrm{~Hz}, 1 \mathrm{H}), 8.14(\mathrm{dd}, \mathrm{J}=1.6,8.4 \mathrm{~Hz}, 1 \mathrm{H}), 7.86(\mathrm{~d}, \mathrm{~J}=8.4 \mathrm{~Hz}, 1 \mathrm{H}), 7.79(\mathrm{~d}, \mathrm{~J}=$ $7.6 \mathrm{~Hz}, 1 \mathrm{H}$ ), $7.75\left(\mathrm{t}, \mathrm{J}=8.0 \mathrm{~Hz}, 1 \mathrm{H}\right.$ ), $7.57\left(\mathrm{t}, \mathrm{J}=7.6 \mathrm{~Hz}, 1 \mathrm{H}\right.$ ). ${ }^{13} \mathrm{C}\left\{{ }^{1} \mathrm{H}\right\} \mathrm{NMR}$ (DMSO-d $\mathrm{d}_{6}$ ): 178.33, 166.75, $141.66,136.42,133.71,132.70,130.64,129.55,129.34,128.64,128.54,127.63,127.47,127.07$.

Compound 33 (10,10-dioxothioxanthone-2-carboxlic acid). Thioxanthone-2-carboxylic acid 32 (2.4 g, 8.3 mmol) was mixed with acetic acid $(70 \mathrm{~mL})$ and then $30 \%$ hydrogen peroxide solution $(2.5 \mathrm{~mL}, 24 \mathrm{mmol})$ was added. The result was heated to reflux for 4 hours and then allowed to cool to room temperature and deionized water $(20 \mathrm{~mL})$ was added. As it cooled the product precipitated out. It was then collected by vacuum filtration and washed with fresh water. After drying in a vacuum oven, $1.8 \mathrm{~g}$ (67\% yield) of product was obtained as an off-white solid. The melting point was measured to be $275-276^{\circ} \mathrm{C}$ (lit $\left.=276^{\circ} \mathrm{C}\right) .{ }^{1} \mathrm{H}$ NMR (DMSO-d 6 ) $\delta: 13.9(\mathrm{br} \mathrm{s}, 1 \mathrm{H}), 8.71(\mathrm{~d}, \mathrm{~J}=1.5 \mathrm{~Hz}, 1 \mathrm{H}), 8.50(\mathrm{dd}, \mathrm{J}=1.6,8.0 \mathrm{~Hz}, 1 \mathrm{H})$, $8.35(\mathrm{~d}, \mathrm{~J}=8.0 \mathrm{~Hz}, 1 \mathrm{H}), 8.32(\mathrm{dd}, \mathrm{J}=1.2,7.8 \mathrm{~Hz}, 1 \mathrm{H}), 8.25(\mathrm{dd}, \mathrm{J}=0.9,7.6 \mathrm{~Hz}, 1 \mathrm{H}), 8.08(\mathrm{dt}, \mathrm{J}=1.3,7.6 \mathrm{~Hz}$, 1H), 7.99 (dt, J = 1.0, 8.0 Hz, 1H). ${ }^{13} \mathrm{C}\left\{{ }^{1} \mathrm{H}\right\}$ NMR (DMSO-d $\mathrm{d}_{6}$ ): 177.85, 165.75, 143.47, 140.36, 136.17, $135.90,135.86,134.59,130.88,130.32,129.81,129.53,124.66,123.96$. 
Compound 35 (bis(10,10-dioxothioxanthone-2-carboxamide) terminated PDMS, $x=40)$. 10,10Dioxothioxanthone-2-carboxylic acid $33(0.48 \mathrm{~g}, 1.7 \mathrm{mmol}$ ) was combined with thionyl chloride $(3 \mathrm{~mL}, 41$ $\mathrm{mmol}$ ) and a small amount of pyridine ( 2 drops) and heated to reflux under nitrogen for 2 hours. The excess thionyl chloride was removed under vacuum on a rotary evaporator, then a few $\mathrm{mLs}$ of petroleum ether was added and this was evaporated off as well. The resulting solid residue was cooled to room temperature and mixed with THF $(6 \mathrm{~mL})$ under nitrogen. A solution of Gelest DMS-A15 (2.5 g, $1.7 \mathrm{mmol})$ and triethylamine $(0.3 \mathrm{~mL}, 2.2 \mathrm{mmol})$ in THF $(4 \mathrm{~mL})$ was then added. After stirring 2 hours, a small amount of Celite was added and the mixture was filtered to remove solids. The THF was then removed under vacuum and the residue thus obtained was dissolved in chloroform. The solution was washed twice with deionized water and once with saturated sodium chloride. After drying over anhydrous potassium carbonate, the chloroform was removed under reduced pressure on a rotary evaporator. The result was $2.52 \mathrm{~g}$ (85\% yield) product as a yellow rubbery solid. ${ }^{1} \mathrm{H} N M R\left(\mathrm{CDCl}_{3}\right) \delta: 8.61$ $(\mathrm{s}, 2 \mathrm{H}), 8.34(\mathrm{t}, \mathrm{J}=7.4 \mathrm{~Hz}, 4 \mathrm{H}), 8.22(\mathrm{~d}, \mathrm{~J}=8.0 \mathrm{~Hz}, 2 \mathrm{H}), 8.18(\mathrm{~d}, \mathrm{~J}=8.0 \mathrm{~Hz}, 2 \mathrm{H}), 7.91(\mathrm{t}, \mathrm{J}=7.6 \mathrm{~Hz}, 2 \mathrm{H}), 7.82$ $(\mathrm{t}, \mathrm{J}=7.6 \mathrm{~Hz}, 2 \mathrm{H}), 6.71(\mathrm{br} \mathrm{s}, \mathrm{NHs}), 3.51(\mathrm{q}, \mathrm{J}=6.8 \mathrm{~Hz}, 4 \mathrm{H}), 1.72(\mathrm{~m}, 4 \mathrm{H}), 0.65(\mathrm{~m}, 4 \mathrm{H}), 0.05-0.16(\mathrm{~m}$, 277H). ${ }^{13} \mathrm{C}\left\{{ }^{1} \mathrm{H}\right\}$ NMR $\left(\mathrm{CDCl}_{3}\right): 177.76,164.61,142.74,140.77,139.31,134.93,133.64,133.42,130.66$, $130.40,129.30,126.87,124.17,123.62,43.38,23.51,15.53,1.38,1.19,1.08,1.01,0.64,0.13$.

Compound 36 (10,10-dioxothioxanthone-2-carboxamide terminated branched polymer). 10,10Dioxothioxanthone-2-carboxylic acid $33(1.8 \mathrm{~g}, 6.2 \mathrm{mmol}$ ) was combined with thionyl chloride (10 $\mathrm{mL}$, $137 \mathrm{mmol}$ ) and a small amount of pyridine $(0.1 \mathrm{~g})$ and heated to reflux under nitrogen for 1.5 hours. At this point the excess thionyl chloride was removed on a rotary evaporator. Petroleum ether $(20 \mathrm{~mL})$ was added and this was removed on the rotary evaporator as well. The solid acid chloride was then mixed with THF ( $30 \mathrm{~mL}$ ) and stirred under nitrogen. A solution of branched aminosilicone 11 (11.35 g, $6.2 \mathrm{mmol} \mathrm{NH}$ ) and triethylamine $(1.2 \mathrm{~mL}, 8.6 \mathrm{mmol})$ in THF $(20 \mathrm{~mL})$ was then added. After stirring overnight, the reaction mixture was filtered and the clear filtrate was stripped on the rotary evaporator. The residue was then dissolved in chloroform and the resulting solution was washed twice with deionized water. After drying over anhydrous potassium carbonate, the chloroform was removed under reduced pressure yielding $11.77 \mathrm{~g}$ (89.8\% yield) of product as a clear-orange, rubbery solid. The melting behavior of this material was evaluated using differential scanning calorimetry (DSC, Perkin-Elmer DSC7, heating rate of $\left.10^{\circ} \mathrm{C} / \mathrm{min}\right)$. The melting endotherm exhibited an Onset Temperature of $54.33^{\circ} \mathrm{C}$, a Peak Temperature of $63.87^{\circ} \mathrm{C}$ and a Delta $\mathrm{H}$ of $3.3491 \mathrm{~J} / \mathrm{g} .{ }^{1} \mathrm{H}$ NMR $\left(\mathrm{CDCl}_{3}\right) \delta: 8.60(\mathrm{~s}, 4 \mathrm{H}), 8.33(\mathrm{~m}, 8 \mathrm{H}), 8.19$ $(\mathrm{m}, 8 \mathrm{H}), 7.90(\mathrm{~m}, 4 \mathrm{H}), 7.81(\mathrm{~m}, 4 \mathrm{H}), 6.75(\mathrm{br} \mathrm{s}, \mathrm{NHs}), 3.50(\mathrm{~m}, 8 \mathrm{H}), 1.72(\mathrm{~m}, 8 \mathrm{H}), 0.65(\mathrm{~m}, 8 \mathrm{H}), 0.04-0.16$ (m, 590H). ${ }^{13} \mathrm{C}\left\{{ }^{1} \mathrm{H}\right\}$ NMR $\left(\mathrm{CDCl}_{3}\right): 177.71,164.59,142.70,140.76,139.33,134.91,133.62,133.41,130.64$, $130.40,129.28,126.90,124.13,123.60,43.37,23.51,15.53,1.37,1.18,1.00,0.92,0.83,0.72,0.64,0.54$, $0.13,-2.32$.

Compound 37 (thioxanthone-2-carboxamide terminated branched polymer). Thioxanthone-2-carboxylic acid 32 ( $0.50 \mathrm{~g}, 1.95 \mathrm{mmols})$ was mixed with thionyl chloride ( $3 \mathrm{~mL}, 41 \mathrm{mmols})$ and a catalytic amount of pyridine ( 3 drops) and heated to reflux under nitrogen for two hours. The excess thionyl chloride was removed under reduced pressure. Petroleum ether was added and this was then stripped as well. The crude acid chloride thus produced was dissolved in THF $(5 \mathrm{~mL})$ and this was added to a solution of branched aminosilicone 11 (3.54g, 1.9 mmols $\mathrm{NH}_{2}$ ) and triethylamine (0.3 mL, 2 mmols) in THF (5 mL). 
After 2.5 hours the reaction mix was filtered and the THF removed under reduced pressure. The residue was dissolved in chloroform and washed twice with deionized water and once with saturated sodium chloride solution. After drying over anhydrous potassium carbonate, the chloroform was removed under reduced pressure yielding $2.9 \mathrm{~g}$ (74\% yield) of product as a viscous oil. ${ }^{1} \mathrm{H} \mathrm{NMR}\left(\mathrm{CDCl}_{3}\right) \delta: 8.87$ (s, $3 \mathrm{H}), 8.63(\mathrm{~d}, \mathrm{~J}=8.0 \mathrm{~Hz}, 3 \mathrm{H}), 8.22(\mathrm{~d}, \mathrm{~J}=8.8 \mathrm{~Hz}, 3 \mathrm{H}), 7.5-7.7(\mathrm{~m}, 15 \mathrm{H}) 6.58(\mathrm{br} \mathrm{s}, \mathrm{NHs}), 3.52(\mathrm{q}, \mathrm{J}=6.8 \mathrm{~Hz}$, $8 \mathrm{H}), 1.77(\mathrm{~m}, 8 \mathrm{H}), 0.66(\mathrm{~m}, 8 \mathrm{H}), 0.06-0.16 \mathrm{~m}(736 \mathrm{H}) .{ }^{13} \mathrm{C}\left\{{ }^{1} \mathrm{H}\right\} \mathrm{NMR}\left(\mathrm{CDCl}_{3}\right): 179.55,165.83,140.52,132.72$, $132.69,131.60,129.95,128.99,128.96,128.50,126.77,126.68,126.12,43.12,23.66,15.55,1.39,1.19$, $1.02,0.93,0.85,0.73,0.65,0.56,0.14,-2.31$. 